\title{
Cromosom: Aplikasi Crowdsourced Software Engineering Menggunakan Komponen Rekomendasi Task Berbasis Media Sosial
}

\author{
Kurnia Ramadhan Putra ${ }^{\mathbf{1}}$, Muhammad Zuhri Catur Candra ${ }^{2}$ \\ ${ }^{1}$ Program Studi Sistem Informasi, Fakultas Teknik Industri, ITENAS, Bandung \\ ${ }^{2}$ Program Studi Magister Informatika, STEI, ITB, Bandung \\ Email: kurniaramadhan@itenas.ac.id ${ }^{1}$, catur@informatika.org ${ }^{2}$
}

\begin{abstract}
ABSTRAK
Konsep crowdsourcing dapat dimanfaatkan pada bidang rekayasa perangkat lunak yang dikenal dengan Crowdsourced Software Engineering (CSE). CSE digunakan untuk menyelesaikan task yang berkaitan dengan perangkat lunak, seperti desain, implementasi, dan pengujian perangkat luna serta perbaikan bug. Saat ini, permasalahan umum yang terjadi aplikasi CSE adalah worker menghabiskan waktu untuk menemukan task yang relevan sesuai dengan keahliannya dan requester sulit untuk memilih worker yang dapat dipercaya untuk mengerjakan task. Komponen sistem rekomendasi dapat diintegrasikan pada aplikasi CSE yang dipercaya mampu untuk mengatasi permasalahan tersebut. Beberapa penelitian yang ada tentang integrasi komponen sistem rekomendasi pada aplikasi CSE hanya untuk menangani rekomendasi task dan tidak memepertimbangkan trustworthiness dari worker yang akan mengerjakan task. Sedangkan pada penelitian ini, integrasi komponen sistem rekomendasi selain dapat membantu merekomendasikan task kepada worker juga melakukan perangkingan terhadap worker berdasarkan trustworthiness dari worker tersebut sehingga dapat menjadi pertimbangan untuk requester dalam memilih worker yang akan mengerjakan task. Pendekatan yang diusulkan pada penelitian ini adalah kombinasi antara pendekatan content based dengan individual based. Pendekatan content based untuk menangani proses pencocokan antara kebutuhan keahlian yang diperlukan untuk mengerjakan task dengan kualifikasi worker yang akan mengerjakan task. Sedangkan pendekatan individual based untuk menangani proses perhitungan nilai social profile dalam menghasilkan trustworthiness dari worker. Implementasi dilakukan dengan mengembangkan aplikasi CSE yang dikenal dengan Cromosom, yang diintegrasikan dengan komponen sistem rekomendasi untuk membantu merekomendasikan task kepada worker dan melakukan perangkingan terhadap worker berdasarkan trustworthiness dari worker tersebut. Dari hasil pengujian fungsionalitas yang dilakukan, aplikasi Cromosom dapat membantu worker untuk menemukan task yang lebih relevan sesuai dengan keahliannya, dan membantu requester dalam memilih worker yang memiliki trustworthiness untuk mengerjakan task.
\end{abstract}

Kata kunci: crowdsourcing, crowdsourced software engineering, task recommendation.

\begin{abstract}
The concept of crowdsourcing can be utilized in the field of software engineering known as Crowdsourced Software Engineering (CSE). CSE is used to address tasks related to software, such as design, implementation, and testing of software and bug fixes. Currently, a common problem that occurs with CSE applications is that workers spend time finding relevant tasks according to their expertise and requester is difficult to choose workers who can be trusted to do the task. The recommendation system component can be integrated into CSE applications that are believed to be able to overcome these problems. Some existing research on the integration of recommendation system components in CSE applications is only to handle task recommendations and not consider the
\end{abstract}


trustworthiness of workers who will be working on tasks. Whereas in this study, the integration of recommendation system components in addition to being able to help recommend tasks to workers also rank workers based on the trustworthiness of the workers so that they can be considered for the requester in choosing workers who will do the task. The approach proposed in this study is a combination of content-based and individual-based approaches. Content-based approach to handle the matching process between the skill requirements needed to do the task and the qualifications of the worker who will be working on the task. While the individual-based approach to handle the process of calculating the value of social profiles in generating trustworthiness from workers. Implementation is done by developing a CSE application known as a Cromosom, which is integrated with the recommendation system component to help recommend tasks to workers and rank workers based on the trustworthiness of the worker. From the results of the functionality testing, the Cromosom application can help workers find more relevant tasks according to their expertise, and help requester in choosing workers who have trustworthiness to do the task.

Keywords: crowdsourcing, crowdsourced software engineering, task recommendation.

\section{PENDAHULUAN}

Perusahaan dapat mengalihdayakan pekerjaaan kepada tenaga kerja yang ada di luar perusahaan yang dikenal dengan istilah outsourcing. Permasalahan yang biasa muncul dalam kegiatan outsourcing adalah sulitnya menemukan tenaga kerja yang memiliki keahlian terkait dengan pekerjaan yang diberikan dan mahalnya upah yang harus dibayarkan. Crowdsourcing diperkenalkan oleh Jeff Howie pada tahun 2006 yang mendefinisikan crowdsourcing sebagai aktivitas untuk mengalihdayakan pekerjaan ke sekelompok orang yang terhubung ke jaringan internet secara open call [1]. Crowdsourcing sebagai solusi alternatif untuk mengurangi biaya yang harus dikeluarkan perusahaan dan memanfaatkan tenaga kerja lebih efisien [2], selain itu juga meningkatkan produktivitas dari perusahaan [3].

Crowdsourcing dapat dimanfaatkan dalam bidang Rekayasa Perangkat Lunak yang dikenal dengan istilah Crowdsourced Software Engineering (CSE). Beberapa pekerjaan pada CSE diantaranya desain arsitektur, pengembangan komponen, dan perbaikan bug [4]. Kegiatan dalam memilih task pada platform CSE saat ini masih dilakukan secara manual sehingga menghabiskan waktu dan sulitnya menemukan worker yang dapat dipercaya untuk mengerjakan task [5]. Salah satu platform CSE yang terkenal adalah Top Coder, dimana ada sekitar 60 task aktif setiap harinya yang dipilih secara manual oleh worker. Sistem rekomendasi dapat diintegrasikan pada platform CSE untuk membantu worker dalam menemukan task yang relevan dan menganilisi preferensi worker terhadap task yang akan dikerjakan [6].

Ada beberapa penelitian yang telah dilakukan mengenai integrasi sistem rekomendasi pada platform crowdsourcing. Penelitian yang dilakukan oleh M. C. Yuen dkk (2011) mengusulkan sebuah algoritma untuk melakukan pencocokan antara keahlian worker dengan task yang direkomendasikan [7]. King dkk (2014) memperkenalkan sebuah framework yang diberi nama TaskRec yang mampu merekomendasikan item cold start kepada worker [8]. Yang dkk (2017) mengusulkan metode yang memanfaatkan deskripsi task dan dan task yang populer untuk direkomendasikan kepada cold start developer.

Pada penelitian sebelumnya, platform crowdsourcing hanya untuk menangani rekomendasi task kepada worker tetapi tidak mempertimbangkan trustworthiness dari worker yang akan mengerjakan task. Sedangkan pada penelitian ini, selain merekomendasikan task kepada worker juga 
merekomendasikan worker kepada requester berdasarkan trustworthiness, sehingga menjadi dasar pertimbangan requester dalam memilih worker yang akan mengerjakan task.

Media sosial dapat dimanfaatkan untuk menjaring worker dengan keahlian beragam [9]. Github adalah repositori kode program sekaligus media sosial yang digunakan untuk berkolaborasi dalam mengembangkan perangkat lunak. Pada penelitian ini, Github digunakan untuk menjaring worker dengan keahlian beragam dan membangun trustworthiness dari worker berdasarkan reputasi, kredensial, dan keahliannya. Berdasarkan latar belakang tersebut, maka dikembangkan platform CSE yang dikenal dengan Cromosom untuk menangani task kode program yang diintegrasikan dengan sistem rekomendasi agar mampu merekomendasikan task kepada worker dan juga melakukan perangkingan terhadap worker berdasarkan trustworthiness sehingga menjadi dasark pertimbangan untuk requester dalam memilih worker yang akan mengerjakan task.

\section{METODOLOGI}

Cromosom adalah singkatan dari Crowdsourced Software Engineering Application Using Recommendation Component Based on Social Media. Ada dua aktor pada aplikasi Cromosom, yaitu requester adalah user yang mempublikasikan task dan worker adalah user yang mengerjakan task, sedangkan task adalah pekerjaan yang harus diselesaikan oleh worker dalam bentuk solusi kode program. Komponen sistem rekomendasi yang diintegrasikan pada aplikasi Cromosom sebagai berikut:

1) Komponen Task Matching, proses untuk mencocokkan antara keahlian yang dibutuhkan untuk mengerjakan task dengan kualifikasi worker.

2) Komponen Social Profile Computation, proses untuk menghitung trustworthiness dari worker.

3) Komponen Top $N$ Recommendation, proses untuk melakukan perangkingan task yang akan direkomendasikan kepada worker berdasarkan hasil perhitungan dari Task Matching dan Social Profile Computation.

Untuk memberikan gambaran umum dari keterkaitan antar komponen pada arsitektur aplikasi Cromosom maka dapat dilihat "Gambar 1".

Penjelasan dari Gambar 1 sebagai berikut:

1) Pengumpulan dataset user dilakukan dengan mengakses API user dari Github (https://developer.github.com/v3/users/), dimana dataset yang dihasilkan dalam format file .json kemudian data tersebut disimpan ke database Cromosom pada Tabel User. Daftar task yang direkomendasikan oleh aplikasi Cromosom secara bebas dapat dipilih oleh worker untuk dikerjakan.

2) Dataset user yang sudah disimpan pada database kemudian direpresentasikan menjadi data worker dimana dilakukan pemilihan atribut yang hanya dibutuhkan sebagai kualifikasi dari worker untuk digunakan pada proses task matching. Requester dapat melihat hasil pengerjaan task, kemudian dievaluasi dan hasil pengerjaan task yang paling baik akan diberikan imbalan sesuai dengan yang telah ditentukan. 


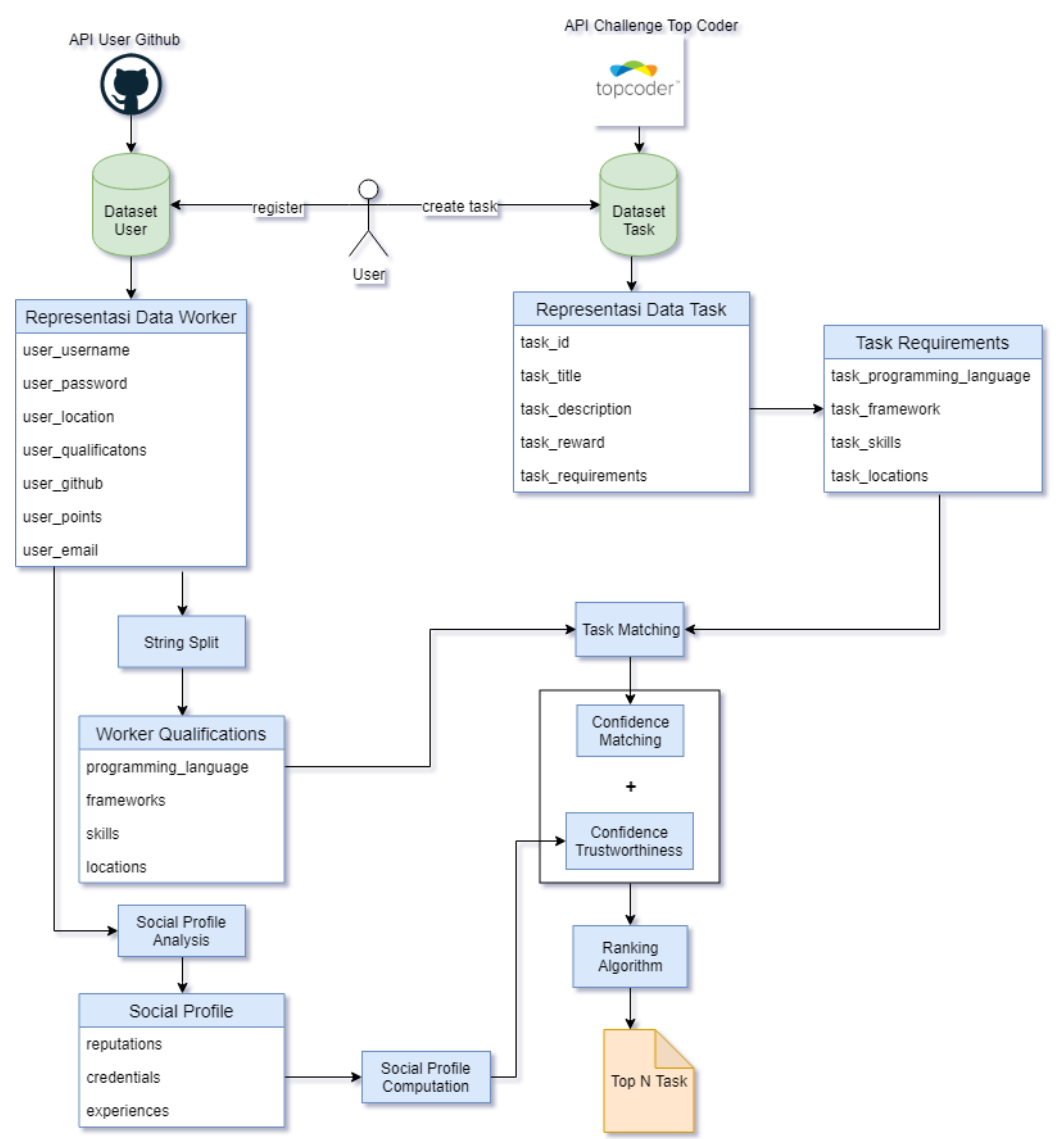

Gambar 1. Gambaran Umum Arsitektur Aplikasi Cromosom

3) Pengumpulan dataset task dilakukan dengan mengakses API challenge dari Top Coder (www.topcoder.com), dimana dataset yang dihasilkan dalam format file json kemudian data tersebut disimpan ke database Cromosom.

4) Dataset task yang sudah disimpan pada database kemudian direpresentasikan menjadi data task dimana dilakukan pemilihan atribut yang hanya dibutuhkan untuk proses task matching.

5) Setelah diperoleh hasil representasi task dan representasi user maka selanjutnya dilakukan proses task matching menggunakan teknik String Distance untuk menghitung kemiripan antara keahlian yang dibutuhkan untuk mengerjakan task dengan kualifikasi worker. Nilai dari hasil dari proses task matching adalah confidence matching dimana nilainya berada pada rentang 0 sampai 1.

6) Social Profile Analysis dilakukan untuk mendapatkan parameter yang akan digunakan untuk menghitung nilai trustworthiness pada tahap Social Profile Computation, diantaranya reputasi, kredensial, dan pengalaman.

7) Proses dari Social Profile Computation akan menghasilkan nilai confidence trustworthiness dari worker.

8) Nilai confidence matching dikombinasikan dengan nilai confidence trustworthiness dengan bobot masing-masing 50\% dan 50\%, sehingga didapatkan nilai akhir confidence yang dirangking sehingga diperoleh top- $n$ task.

\subsection{Analisis Task Matching}

Pada penelitian ini, dilakukan analisis bahwa salah satu teknik yang dapat digunakan untuk menangani proses task matching yaitu String Distance. String Distance adalah teknik untuk menghitung kemiripan antara dua string. Pada dataset user Github, user mendeskripsikan kualifikasinya dalam bentuk string kalimat atau kumpulan dari beberapa kata, sehingga kalimat tersebut perlu diuraikan 
menjadi beberapa string kata, agar dapat dilakukan perhitungan jarak antara string kata dari keahlian yang dibutuhkan untuk mengerjakan task dengan string kata dari kualifikasi worker. Hasil pemisahan dari string kalimat menjadi string kata dapat dilihat pada "Tabel 1".

Tabel 1. Hasil Split Dari String Kalimat

\begin{tabular}{lcl}
\hline \multicolumn{1}{c}{ String Kalimat } & Array & \multicolumn{1}{c}{ String Kata } \\
\hline Javascript Java Spring AngularJS & 0 & Javascripts \\
MySQL & 1 & Java \\
& 2 & Spring \\
& 3 & AngularJS \\
& 4 & MySQL \\
\hline
\end{tabular}

Kemudian dilakukan perhitungan kemiripan antara keahlian yang dibutuhkan untuk mengerjakan task dengan kualifikasi worker menggunakan algoritma Levenshtein Distance seperti yang ditunjukkan pada "Tabel 2".

Tabel 2. Hasil Perhitungan Algoritma Levenshtein Distance

\begin{tabular}{lllc}
\hline $\begin{array}{l}\text { Kualifikasi } \\
\text { Worker }\end{array}$ & \multicolumn{2}{l}{ Kebutuhan Keahlian } & $\begin{array}{l}\text { Levenshtein } \\
\text { Distance }\end{array}$ \\
\hline Javascript & Task1 & javascript & 0.9 \\
& Task2 & java & 0.571 \\
& Task3 & Spring & 0.3 \\
& Task4 & Angular & 0.1 \\
& Task5 & MySQL & 0.1 \\
\hline
\end{tabular}

Jika nilai hasil perhitungan dari algoritma Levenshtein Distance mendekati 1, maka dapat dinyatakan bahwa kebutuhan keahlian terhadap task cocok dengan keahlian yang dimiliki oleh worker, sebaliknya jika mendekati 0 maka tidak ada kecocokan antara keahlian yang dibutuhkan untuk mengerjakan task kualifikasi yang dimiliki oleh worker.

Berdasarkan hasil perhitungan algoritma Levenshtein Distance, maka dapat dilakukan perangkingan terhadap task seperti pada "Tabel 3".

Tabel 3. Hasil Perangkingan Task

\begin{tabular}{lllcl}
\hline $\begin{array}{l}\text { Kualifikasi } \\
\text { Worker }\end{array}$ & \multicolumn{2}{l}{ Kebutuhan Keahlian } & $\begin{array}{l}\text { Levenshtein } \\
\text { Distance }(\text { LD) }\end{array}$ & Task Ranking \\
\hline Javascript & Task1 & javascript & 0.9 & Task 1 \\
& Task2 & java & 0.571 & Task 2 \\
& Task3 & MySQL & 0.1 & Task 5 \\
& Task4 & Angular & 0.1 & Task 3 \\
& Task5 & Spring & 0.3 & Task 4 \\
\hline
\end{tabular}

Dari "Tabel 3" dapat dilihat dari hasil perangkingan task bahwa task yang paling cocok direkomendasikan adalah Task1 dengan nilai tertinggi yaitu 0,9. 


\subsection{Analisis Social Profile Computation}

Langkah-langkah dari analisis perhitungan social profile digunakan untuk mendapatkan nilai trustworthiness dari worker, yang dapat dijelaskan sebagai berikut:

1) Membangun Jaringan Sosial User

Pada tahap ini dilakukan pembangunan jaringan sosial dari 1442 user berdasarkan relasi yang terjalin antar user tersebut. Relasi antar user dinotasikan dalam sebuah array dimana jika panjang array lebih besar dari nol maka menunjukkan adanya relasi antar satu user dengan user lainnya. Jaringan sosial user dibentuk menjadi sebuah graf yang terdiri dari sekumpulan node yang menunjukkan user dan sekumpulan edge yang menunjukkan relasi yang terjalin antar user tersebut

2) Merepresentasikan Trustworthiness

Pada tahap ini dilakukan pembangunan jaringan sosial dari 1442 user berdasarkan relasi yang terjalin antar user tersebut. Relasi antar user dinotasikan dalam sebuah array dimana jika panjang array lebih besar dari nol maka menunjukkan adanya relasi antar satu user dengan user lainnya.

3) Perhitungan Nilai Trustworthiness

Hasil perhitungan reputation, credentials, dan experiences digabungkan sehingga didapatkan nilai trustworthiness, dimana:

$$
\text { ConfidenceTrustworthiness }=\left(\left(\frac{\text { reputation }}{a}+\frac{\text { credentials }}{a}+\frac{\text { Experiences }}{a}\right) \times 100 \%\right)
$$

Dimana,

a. Skor reputation adalah nilai kombinasi antara skor success rate dengan skor relationship.

$$
\text { reputation }=\frac{\text { success rate }+ \text { relationship }}{2}
$$

Dimana,

- success rate adalah jumlah task yang diterima oleh requester dibandingkan dengan jumlah task yang dikerjakan oleh worker.

Contoh skenario: Jumlah task yang dikerjakan oleh worker adalah 5 task sedangkan jumlah task yang diterima oleh requester adalah 3, sehingga skor success rate dari worker adalah $3 / 5$ sama dengan 0,6 .

- relationship adalah adanya relasi antara requester dengan worker maka skor relationship sama dengan 1 dan jika tidak ada relasi maka skor relationship sama dengan 0.

Contoh skenario: Requester memiliki relasi dengan worker maka skor relationship sama dengan 1.

reputation $=\frac{\text { success rate }+ \text { relationship }}{2}=\frac{0,6+1}{2}=\frac{1,6}{2}=0,8$

b. Setelah diperoleh skor reputation, credentials, dan experiences, maka nilai dapat dihitung nilai ConfidenceTrustworthiness sebagai berikut:

$$
\begin{aligned}
\text { ConfidenceTrustworthiness } & =\left(\left(\frac{0,9}{a}+\frac{1}{a}+\frac{0,8}{a}\right) \times 100 \%\right) \\
= & (0,27+0,33+0,27)=0,87 \times 100 \% \\
= & 87 \%
\end{aligned}
$$




\subsection{Analisis Top $N$ Recommendation}

Langkah-langkah dari analisis top-n task recommendation dijelaskan sebagai berikut:

1) Skor yang sudah diperoleh dari hasil proses task matching kemudian dikombinasikan dengan skor yang diperoleh dari perhitungan social profile computation dengan bobot masing-masing sebesar $50 \%$ dan $50 \%$.

2) Hasil skor dari kombinasi antara proses task matching dengan perhitungan social profile computation, dilakukan perangkingan yang diurutkan berdasarkan 10 task dengan perolehan skor confidence matching ditambah confidence trustworthiness tertinggi.

\section{PERANCANGAN APLIKASI}

\subsection{Rancangan Kebutuhan Fungsional}

Kebutuhan fungsional dari aplikasi Cromosom dijelaskan pada "Gambar 2".

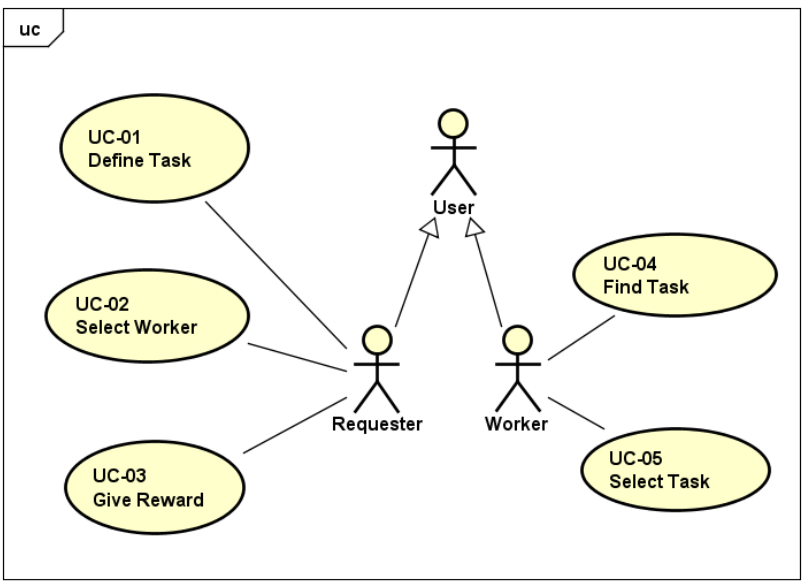

Gambar 2. Diagram Use Case Aplikasi Cromosom

Penjelasan dari masing-masing use case dijabarkan pada "Tabel 4".

Tabel 4. Deskripsi Diagram Use Case

\begin{tabular}{cll}
\hline No. Use Case & Nama Use Case & \multicolumn{1}{c}{ Deskripsi } \\
\hline UC-01 & Define Task & $\begin{array}{l}\text { Requester mampu mendefinisikan task yang } \\
\text { akan di-outsource dengan mendeskripsikan } \\
\end{array}$ \\
& informasi dari task tersebut, seperti title, \\
& description, duration, programming language, \\
& frameworks, skills, location, dan rewards. \\
& Kemudian requester mempublikasikan task \\
& yang sudah didefinisikan tersebut ke aplikasi \\
& Cromosom \\
\hline UC-02 & Requester mampu memilih worker yang akan \\
& mengerjakan task sesuai dengan hasil \\
& perangkingan aplikasi Cromosom. \\
\hline UC-03 & Give Reward & Requester mampu memberikan reward kepada \\
& worker jika hasil pengerjaan task diterima. \\
\hline UC-04 & Worker mampu mencari task yang sesuai \\
\hline
\end{tabular}




\begin{tabular}{ccl}
\hline No. Use Case & Nama Use Case & \multicolumn{1}{c}{ Deskripsi } \\
\hline & & dengan keahliannya \\
\hline UC-05 & Select Task & Worker mampu memilih task yang \\
& & direkomendasikan oleh aplikasi Cromosom. \\
\hline
\end{tabular}

\subsection{Rancangan Alur Kerja Aplikasi Cromosom}

Alur kerja pada aplikasi Cromosom diilustrasikan menggunakan activity diagram seperti pada "Gambar 3" dengan langkah-langkah sebagai berikut:

1) Requester mendefinisikan task yang akan dikerjakan oleh worker, kemudian task tersebut dipublikasikan, dan aplikasi akan menyimpan task tersebut pada database.

2) Task yang sudah disimpan pada database direpresentasikan berdasarkan atribut yang hanya dibutuhkan untuk proses task matching, yaitu task requirements, diantaranya programming language, framework, skills, dan location.

3) Worker dapat melakukan login pada aplikasi Cromosom secara langsung dengan memasukkan username dan password atau menggunakan otorisasi media sosial Github.

4) Profil dari worker direpresentasikan berdasarkan atribut yang hanya dibutuhkan untuk untuk proses task matching, yaitu worker qualifications.

5) Pada proses task matching, dilakukan perhitungan untuk mencari kedekatan nilai atau kemiripan antara task requirements dengan worker qualifications.

6) Pada proses social profile computation, dilakukan perhitungan dengan menjumlahkan nilai reputation, credentials, dan experiences. Hasil perhitungan tersebut akan menghasilkan nilai confidence trustworthiness.

7) Nilai confidence matching dengan nilai confidence trustworthiness digabungkan kemudian dilakukan perangkingan sehingga menghasilkan top 10 task dengan nilai tertinggi yang akan direkomendasikan kepada worker.

8) Hasil perhitungan dari proses task matching akan menghasilkan nilai condidence matching.

9) Worker memilih salah satu task yang direkomendasikan tersebut, kemudian requester mendapat notifikasi bahwa task sudah dipilih oleh beberapa orang worker, kemudian worker dirangking berdasarkan nilai trustworthiness.

10) Worker dengan perolehan skor tertinggi dapat diterima oleh requester untuk mengerjakan task.

11) Worker yang diterima oleh requester, dapat mengerjakan task kemudian mengirim hasil pengerjaan task yang diunggah pada repositori Github.

12) Requester dapat mengunduh hasil pengerjaan task kemudian memeriksa hasilnya, jika hasil pengerjaan task sesuai dengan kebutuhan requester, maka worker akan diberikan reward dalam bentuk poin 


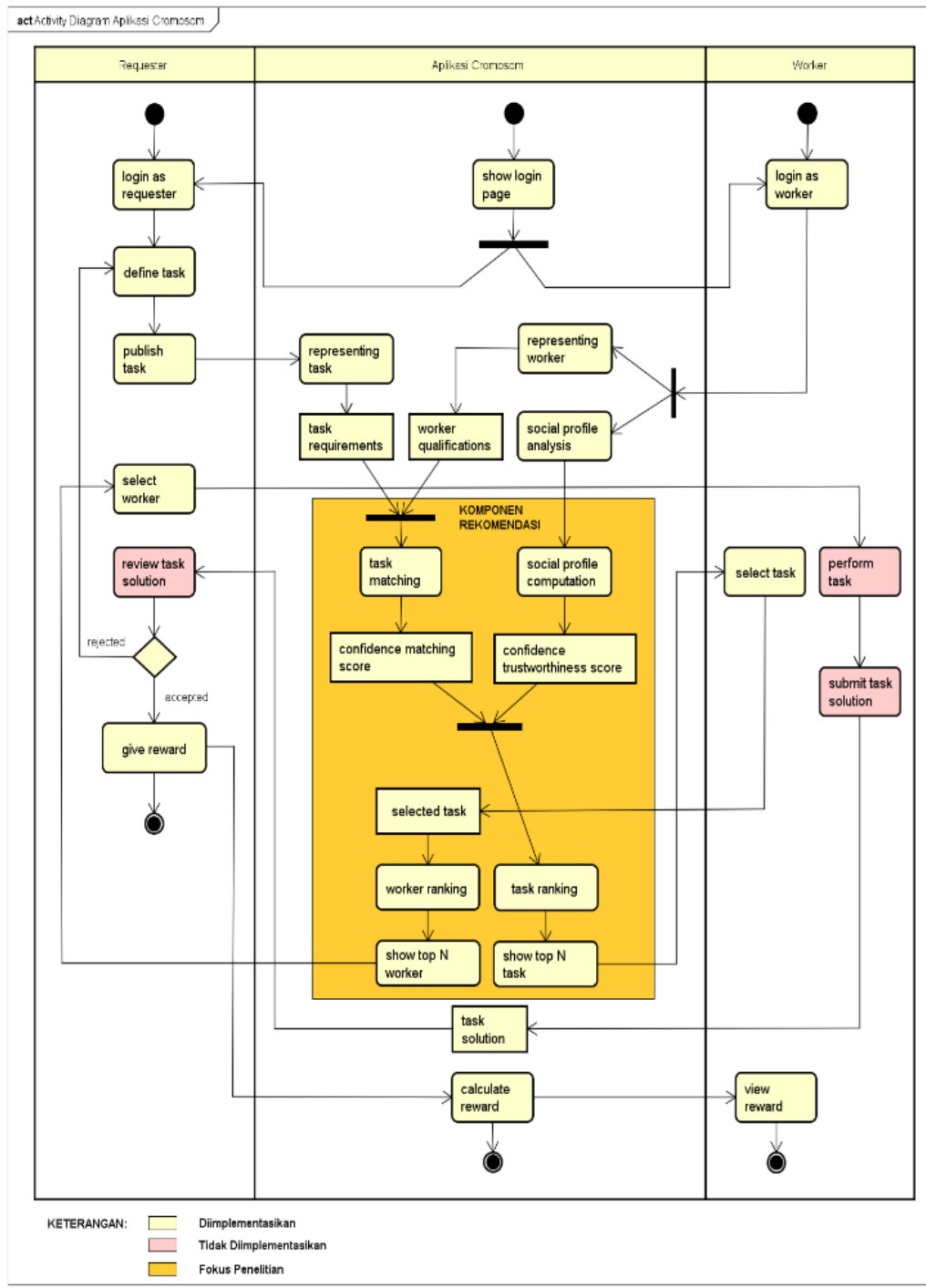

Gambar 3. Diagram Aktivitas Aplikasi Cromosom

\subsection{Rancangan Komponen Sistem Rekomendasi}

\subsubsection{Komponen Task Matching}

Proses task matching dimulai dari pemisahan atribut kebutuhan task menjadi atribut bertipe data diskrit dan kontinu. Atribut dengan tipe data diskrit di dalam proses task matching akan menghasilkan nilai 0 atau 1 (true atau false). Sedangkan atribut dengan tipe data continue akan menghasilkan nilai antara 0 dan 1 (fuzzy). Atribut dengan tipe data diskrit diantaranya programming language, framework, dan skill, sedangkan atribut dengan tipe data kontinu adalah location.

Pada "Tabel 5" dijelaskan contoh proses task matching antara keahlian yang dibutuhkan untuk mengerjakan task dengan kualifikasi worker.

Tabel 5. Perhitungan Proses Task Matching

\begin{tabular}{llllccc}
\hline Parameter & Tipe & $\begin{array}{l}\text { Task } \\
\text { Requirements }\end{array}$ & $\begin{array}{l}\text { Worker } \\
\text { Qualifications }\end{array}$ & $\begin{array}{l}\text { Hasil } \\
\text { Matching }\end{array}$ & $\begin{array}{l}\text { Bobot } \\
\text { Perolehan } \\
\text { Skor }\end{array}$ \\
\hline $\begin{array}{l}\text { Programming } \\
\text { Language }\end{array}$ & Diskrit & Java & Java & 1 & $30 \%$ & 0,3 \\
Frameworks & Diskrit & Spring & Struts & 0 & $40 \%$ & 0 \\
Skills & Diskrit & Undefined & - & - & - & -
\end{tabular}




\begin{tabular}{llllccc}
\hline Parameter & Tipe & $\begin{array}{l}\text { Task } \\
\text { Requirements }\end{array}$ & $\begin{array}{l}\text { Worker } \\
\text { Qualifications }\end{array}$ & $\begin{array}{l}\text { Hasil } \\
\text { Matching }\end{array}$ & $\begin{array}{l}\text { Bobot } \\
\text { Locations }\end{array}$ \\
\cline { 3 - 6 } & Kontinu & Radius = 100 & Radius = 121 & 0,826 & $\begin{array}{l}\text { Perolehan } \\
\text { Skor }\end{array}$ \\
& KM & KM & & 0,247 \\
Confidence Matching & & & & 0,547 \\
\hline
\end{tabular}

Confidence matching adalah nilai yang didapatkan dari penggabungan antara programming language, framework, skills, dan locations. Berdasarkan proses dari Task Matching pada "Tabel 5" diperoleh nilai confidence matching sebesar 0,547.

\subsubsection{Komponen Social Profile Computation}

Berdasarkan hasil dari analisis social profile worker pada media sosial, nilai trustworthiness dari seorang user terhadap user lainnya dapat dipertimbangkan berdasarkan skor reputation, skor credentials, dan skor experiences. Skor reputation dihitung dari atribut success rate dan relationship yang terjalin antar user. Skor credentials diperoleh dengan melihat sertifikat yang dimiliki oleh worker berkaitan dengan bahasa pemograman tertentu, namun pada repositori Github memiliki keterbatasan bahwa tidak adanya sertifikat keahlian worker berkaitan dengan bahasa pemograman. Akan tetapi, setiap repositori proyek yang pernah dikerjakan oleh worker menyimpan informasi bahasa pemograman, sehingga dapat dimanfaatkan untuk perhitungan skor credentials. Pada penelitian ini, skor credentials diperoleh dengan melakukan pengecekan terhadap repositori proyek berkaitan dengan bahasa pemograman apakah memiliki kesamaan kualifikasi yang dideskripsikan oleh worker pada aplikasi Cromosom. Nilai experiences dihitung berdasarkan jumlah commit yang dilakukan oleh worker pada repositori proyek.

Pada "Tabel 6" dijelaskan contoh hasil perhitungan dari confidence trustworthiness.

Tabel 6. Hasil Perhitungan Trustworthiness

\begin{tabular}{|c|c|c|c|c|c|}
\hline Parameter & & Kondisional & $\begin{array}{l}\text { Nilai } \\
\text { Aktual }\end{array}$ & Perhitungan & $\begin{array}{l}\text { Perolehan } \\
\text { Skor }\end{array}$ \\
\hline Reputation & $\begin{array}{l}\text { Relationship } \\
\text { (R) } \\
\text { Success Rate } \\
\text { (SR) }\end{array}$ & $\begin{array}{l}\text { if arrayRelationship }>0 \text { ? } \\
\text { return } 1 \text { else } 0 \\
\text { jumlah task yang diterima } \\
\text { jumlah task yang dikerjakan }\end{array}$ & $\frac{4}{5}=0,8$ & $\begin{array}{l}\mathrm{R}+\mathrm{SR}= \\
=\frac{1+0,8}{2}=0,9 \\
=\frac{0,9}{3}=0,3\end{array}$ & 0,3 \\
\hline Credentials & & $\begin{array}{l}\text { if taskRequirement.language } \\
==\text { repoDetail.language? } \\
\text { return } 1 \text { else } 0\end{array}$ & 1 & $\frac{1}{3}=0,33$ & 0,33 \\
\hline Experiences & & $\frac{\text { worker commit }}{\text { max commit }}$ & $\begin{array}{l}\max \\
\text { commit } \\
=100 \\
\text { worker } \\
\text { commit } \\
=75\end{array}$ & $\begin{array}{l}\frac{75}{100}=0,75 \\
\frac{0,75}{3}=0,25\end{array}$ & 0,25 \\
\hline Confidence $\mathrm{T}$ & lstworthiness & & & & 0,88 \\
\hline
\end{tabular}

Confidence trustworthiness adalah skor yang didapatkan dari penggabungan antara skor reputations, skor credentials, dan skor experiences. Berdasarkan proses dari Social Profile Computation pada "Tabel 6" diperoleh nilai confidence trustwortiness sebesar 0,88. Berdasarkan contoh hasil perolehan 
skor confidence matching pada "Tabel 5" dan hasil perolehan skor confidence trustworthiness pada Tabel 6, maka dapat dilakukan penggabungan skor dengan skenario pembobotan masing-masing sebesar 50\% dan 50\%, dijelaskan pada "Tabel 7".

Tabel 7. Kombinasi Skor Confidence Matching dengan Confidence Trustworthiness

\begin{tabular}{lllll}
\hline Parameter & Skor & Bobot & $\begin{array}{l}\text { Perolehan } \\
\text { Skor }\end{array}$ & $\begin{array}{l}\text { Skor Akhir } \\
\text { Confidence }\end{array}$ \\
\hline Confidence Matching & 0,547 & $50 \%$ & 0,2735 & $0,2735+0,44=0,677$ \\
Confidence Trustworthiness & 0,88 & $50 \%$ & 0,44 & \\
\hline
\end{tabular}

\section{HASIL DAN PEMBAHASAN}

\subsection{Hasil Rekomendasi Task Menggunakan Distribusi Normal}

Representasi numerik dari nilai confidence yang dibagi menjadi 10 skala dengan rentang nilai antara 0 sampai $100 \%$. Untuk setiap rentang nilai dilakukan perhitungan nilai frekuensinya, dimana yang menjadi nilai frekuensi adalah jumlah task yang direkomendasikan. Ada 351 worker yang memperoleh rekomendasi task masing-masing 10 rekomendasi, sehingga total task yang direkomendasikan kepada 351 worker adalah 3.510 task. Pada "Tabel 8" diuraikan distribusi data dari rekomendasi task sesuai dengan rentang nilai confidence.

Tabel 8. Frekuensi Pembagian Nilai Akhir Confidence

\begin{tabular}{ccc}
\hline $\begin{array}{l}\text { Rentang Nilai Confidence } \\
(\mathbf{x})\end{array}$ & $\begin{array}{l}\text { Frekuensi Task Yang } \\
\text { Direkomendasikan }(\mathbf{f})\end{array}$ & Frekuensi Komulatif (fk) \\
\hline & 44 & 44 \\
& 509 & 553 \\
$11-20$ & 297 & 850 \\
$21-30$ & 460 & 1.310 \\
$31-40$ & 1149 & 2.459 \\
$41-50$ & 523 & 2.982 \\
$51-60$ & 301 & 3.283 \\
$61-70$ & 179 & 3.462 \\
$71-80$ & 27 & 3.489 \\
$81-90$ & 21 & 3.510 \\
\hline $1-100$ & &
\end{tabular}

Untuk memberikan gambaran apakah data dari task yang direkomendasikan berdistribusi normal, maka dapat diilustrasikan menggunakan grafik seperti pada "Gambar 4".

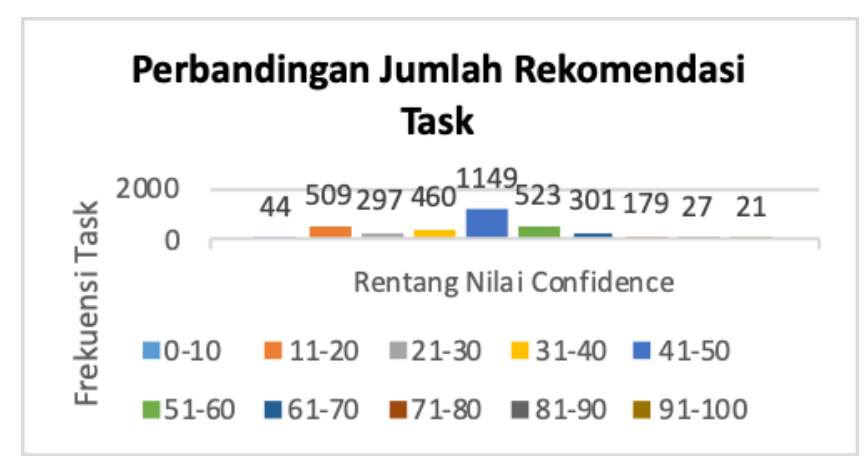

Gambar 4. Grafik Distribusi Normal Nilai AKhir Confidence

Jurnal Itenas Rekayasa - 227 
Dari "Gambar 4" dapat dilihat bahwa rentang persentil nilai akhir confidence dengan rentang nilai antara 41-50 memperoleh frekuensi tertinggi yaitu sebesar 1.149 task yang direkomendasikan. Hal tersebut karena dari hasil perhitungan task matching dan social profile computation menghasilkan rekomendasi task yang lebih banyak dengan rentang nilai confidence antara 41\%-50\%.

Dapat diamati bahwa "Gambar" sudah mendekati distribusi normal yang membentuk "bell curve", namun ada keganjilan yang terjadi pada rentang nilai confidence antara 11-20, dimana seharusnya jumlah task yang direkomendasikan adalah lebih tinggi dari rentang nilai confidence antara 0-10 dan lebih rendah dari rentang nilai confidence antara 21-30.

Hal tersebut terjadi karena perhitungan task matching lebih dominan dalam memberikan nilai untuk menghasilkan rekomendasi task. Perhitungan task matching diperoleh dengan mencocokkan antara task requirements dengan worker qualifications dimana worker pada platform Cromosom ketika melakukan registrasi dapat mendeskripsikan keahliannya terlepas dari data keahlian tersebut benar atau tidak, sehingga perhitungan task matching lebih dominan untuk mendapatkan nilai confidence.

Sedangkan perhitungan social profile computation yang menghasilkan nilai trustworthiness dari worker belum memberikan dampak dari hasil perhitungan dari seluruh task yang direkomendasikan karena (1) perhitungan nilai reputation yaitu belum adanya relationship antara requester dan worker, setiap task yang dipublikasikan oleh requester belum dikerjakan oleh semua worker sehingga worker tidak mendapatkan success rate, (2) perhitungan nilai credentials yaitu banyak worker yang mendeskripsikan kehalian palsu pada platform Cromosom, dan (3) perhitungan nilai experiences yaitu dilihat dari jumlah commit dari worker terhadap proyek masih sedikit sehingga tidak mendapatkan nilai experiences yang maksimal.

\subsection{Hasil Kualitas Rekomendasi Task Menggunakan Persentil}

Untuk menghitung persentil, secara matematis dapat ditulis menggunakan Persamaan.

$P_{i}=T_{b}+\left\{\frac{\frac{i}{100} n-f_{k}}{f_{i}}\right\} p$

Dimana,

$P_{i \mathrm{i}}$ adalah persentil ke-i, dimana $i$ adalah bilangan bulat yang kurang dari $100(1 . .99)$

$T_{b}$ adalah tepi bawah kelas persentil

$n$ adalah jumlah seluruh frekuensi

$f k$ adalah jumlah frekuensi sebelum kelas persentil

$f_{i}$ adalah frekuensi kelas persentil

$p$ adalah panjang kelas interval

Dilakukan pengujian untuk mencari nilai confidence pada persentil ke-10, persentil ke-20, persentil ke-30, persentil ke-40, persentil, ke-50, persentil ke-60, persentil ke-70, persentil ke-80, dan persentil ke-90. Hasil perhitungan persentil nilai confidence diuraikan pada "Tabel 9" 
Tabel 9. Persentil Nilai Akhir Confidence

\begin{tabular}{cc}
\hline Rangking Persentil & Nilai Persentil \\
\hline Persentil 10 & 16,53 \\
Persentil 20 & 25,52 \\
Persentil 30 & 34,91 \\
Persentil 40 & 41,32 \\
Persentil 50 & 44,37 \\
Persentil 60 & 47,43 \\
Persentil 70 & 50,48 \\
Persentil 80 & 57,17 \\
Persentil 90 & 66,38 \\
Persentil 99 & 84,83
\end{tabular}

Untuk memberikan gambaran dari hasil perhitungan persentil, maka maka dapat diilustrasikan menggunakan grafik seperti pada "Gambar 5".

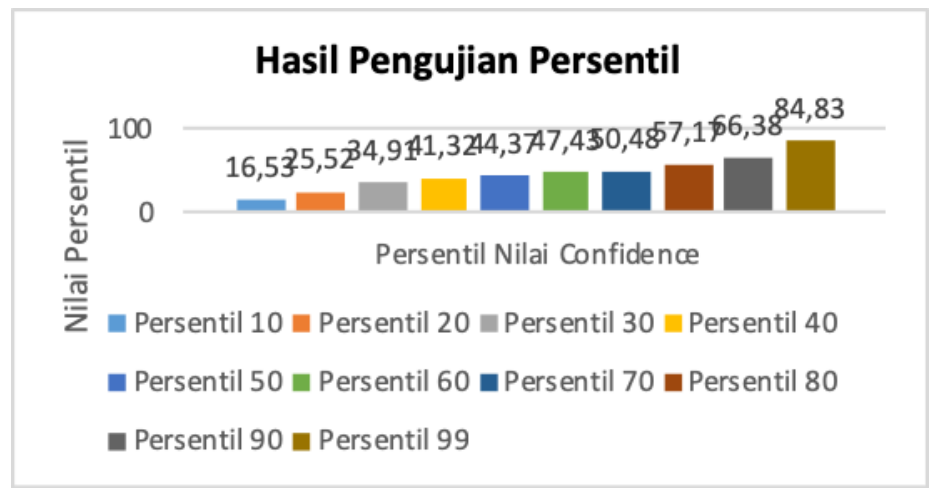

Gambar 5. Hasil Persentil Nilai Confidence

Berdasarkan "Gambar 5" dapat dilihat nilai persentil untuk setiap nilai confidence dimana skala persen nilai confidence yaitu $0<$ persentil $<100$. Dari hasil pengujian dapat dilihat bahwa nilai persentil semakin naik jika persentil nilai confidence mendekati 100. Dari beberapa studi literatur yang dilakukan bahwa seharusnya kurva yang dibentuk dari persentil nilainya akan terus menaik dari kiri ke kanan. Dapat dilihat nilai persentil dari data rekomendasi task menaik dari 0 menuju 100, sehingga dapat disimpulkan kualitas task yang direkomendasikan cukup baik.

\subsection{Kesimpulan}

\section{KESIMPULAN}

Kesimpulan dari penelitian ini adalah sebagai berikut:

1. Berdasarkan fungsionalitasnya, aplikasi Cromosom mampu merekomendasikan task kepada worker yang sesuai dengan keahliannya.

2. Proses Social Profile Computation mampu menghasilkan nilai trustworthiness dari worker sehingga dapat dilakukan perangkingan terhadap worker berdasarkan nilai trustworthiness, dan menjadi dasar untuk requester dalam memilih worker yang tepat dalam mengerjakan task.

3. Berdasarkan hasil pengujian dari distribusi data rekomendasi task bahwa sudah mendekati grafik distribusi normal namun untuk rentang nilai antara 10-20 memiliki simpangan karena faktor perhitungan task matching lebih dominan dalam menghasilkan nilai confidence, dan dari hasil pengujian kualitas data rekomendasi task menghasilkan kualitas yang cukup baik. 


\subsection{Saran}

Saran untuk penelitian selanjutnya adalah:

1. Pada penelitian ini memiliki keterbatasan dalam analisis konten, dimana analisis konten nantinya dapat dimanfaatkan untuk menganalisis kredensial worker dalam bentuk dokumen sertifikat.

2. Untuk melakukan proses task matching nantinya diharapkan dapat dintegrasikan dengan teknik klasifikasi, misalnya naïve bayes dengan tujuan untuk mempercepat waktu proses pencocokan antara task requirement dengan worker qualifications.

3. Semua pendekatan task matching dapat diimplementasikan pada aplikasi Cromosom, sehingga dapat dilakukan perbandingan pendekatan task matching mana yang menghasilkan rekomendasi task yang paling baik.

4. Saat ini, relationship antar user hanya dimanfaatkan untuk menunjukkan adanya relasi antar user untuk perhitungan trustworthiness. Saran untuk penelitian selanjutnya adalah relationship antar user dapat dimodelkan menjadi sebuah graf, sehingga dapat dimanfaatkan untuk membangun social trust antar user.

\section{DAFTAR PUSTAKA}

[1] J. Howe, "The Rise of Crowdsourcing," Wired Mag., vol. 14, no. 06, hal. 1-5, 2006.

[2] J. Howe, "Crowdsourcing: Why the Power of The Crowd is Diving the Future Business," Crown Bus., 2008.

[3] M. Allahbakhsh, B. Benatallah, A. Ignjatovic, H. R. Motahari-Nezhad, E. Bertino, dan S. Dustdar, "Quality control in crowdsourcing systems: Issues and directions," IEEE Internet Comput., vol. 17, no. 2, hal. 76-81, 2013.

[4] K. Mao, L. Capra, M. Harman, dan Y. Jia, "A survey of the use of crowdsourcing in software engineering," J. Syst. Softw., vol. 126, hal. 57-84, 2017.

[5] A. Kass, "Trustworthiness in Enterprise Crowdsourcing: a Taxonomy \& evidence from data," 2016.

[6] K. Mao, Y. Yang, Q. Wang, Y. Jia, dan M. Harman, "Developer recommendation for crowdsourced software development tasks," Proc. - 9th IEEE Int. Symp. Serv. Syst. Eng. IEEE SOSE 2015, vol. 30, hal. 347-356, 2015.

[7] M. C. Yuen, I. King, dan K. S. Leung, "Task matching in crowdsourcing," Proc. - 2011 IEEE Int. Conf. Internet Things Cyber, Phys. Soc. Comput. iThings/CPSCom 2011, no. October, hal. 409-412, 2011.

[8] M. Y. I. King, "TaskRec: A Task Recommendation Framework in Crowdsourcing Systems TaskRec: A Task Recommendation Framework in Crowdsourcing Systems," no. June 2015, 2014.

[9] S. Marjanovic, C. Fry, dan J. Chataway, "Crowdsourcing based business models: In search of evidence for innovation 2.0," Sci. Public Policy, vol. 39, no. 3, hal. 318-332, 2012.

[10] A. Sari, A. Tosun, dan G. I. Alptekin, "A Systematic Literature Review on Crowdsourcing in Software Engineering." The Journal of Systems \& Software, hal. 26, 2018.

[11] T. D. Latoza dan A. Van der Hoek, "Crowdsourcing in Software Engineering," IEEE Softw., 2016.

[12] K. J. Stol, T. D. Latoza, dan C. Bird, "Crowdsourcing for Software Engineering," IEEE Softw., vol. 34, no. 2, hal. 30-36, 2017.

[13] M. Hosseini, A. Shahri, K. Phalp, J. Taylor, R. Ali, dan F. Dalpiaz, "Configuring Crowdsourcing for Requirements Elicitation," 2015.

[14] T. D. Latoza, M. Chen, L. Jiang, M. Zhao, dan A. Van Der Hoek, "Borrowing from the 
Crowd: A Study of Recombination in Software Design Competitions," no. c, hal. 551-562, 2015.

[15] A. van der H. Thomas D. LaToza1, W. Ben Towne2, Christian M. Adriano1, "Microtask Programming: Building Software with a Crowd,” 2014. 